\title{
Tradition of geodetic instruments production in the Czech Republic
}

\author{
Pavel Hánek ${ }^{1,2}$ and Pavel Hánek Sr. ${ }^{1,3}$ \\ ${ }^{1}$ Research Institute of Geodesy, Topography and Cartography, v.v.i., Zdiby, 250 66, Czech Republic \\ ${ }^{2}$ Department of Landscape Management, Faculty of Agriculture, \\ University of South Bohemia in České Budějovice, Budweis, 37005, Czech Republic \\ ${ }^{3}$ Department of Special Geodesy, Faculty of Civil Engineering, \\ Czech Technical University in Prague, Prague, 16629, Czech Republic \\ Correspondence: Pavel Hánek (pavel.hanek@vugtk.cz)
}

Received: 27 May 2021 - Accepted: 27 August 2021 - Published: 7 October 2021

\begin{abstract}
The article describes the development of geodetic surveying and production of geodetic instruments in what is now Czech Republic. The beginnings of development can be found in the 12th-13th centuries during the colonization of the territory and the consolidation of state administration. Significant development peaks occurred in the 14th century during the reign of the Holy Roman Emperor and King of Bohemia Charles IV and then at the turn of the 16th and 17th centuries during the reign of the Holy Roman Emperor Rudolf II. The new direction is related to the development of industry at the end of the 19th century. At that time, several dozen companies in fine mechanics and optics were operating in Prague. The company J. \& J. Frič was a world leader in the use of a glass divided circle in 1864. The production of astronomical and geodetic instruments in Czechoslovakia was successful until the end of the 1960s.
\end{abstract}

\section{Introduction}

The Czech Republic consists of the historical lands of Bohemia, Moravia and parts of Silesia. This area has always been a busy crossroads of European cultural influences, military and economic interests. In history, there were periods when it belonged to the most important European states.

The internal and external colonization of the Bohemian lands lasted from the 12th to the beginning of the 15th century. In particular, the last rulers of the Přemyslid dynasty and some members of the leading Czech aristocratic families founded 45 cities, 25 castles and 34 important church buildings in addition to a number of smaller settlements in Bohemia and neighbouring countries. The farthest was Königsberg in the Baltic region, today's Russian Kaliningrad. In Bohemia, the second peak of the general development was the reign of the Holy Roman Emperor and Bohemia king Charles IV (1316-1378). The construction of the New Town of Prague was one of Europe's largest and most important in terms of thought and scope. It was built using a landscape configuration, usually on a chequerboard floor plan with a central square. Of course, the participation of lokators (Latin for locator) from the ranks of close collaborators of the emperor was necessary. They had to master the geodetic works. The measuring instruments, tools and procedures of that time were based on the experience of Roman agrimensores, especially from the writings of Anicii Manlii Torquati Severini Boethii (480-524/5), which were modified and amended in the following centuries (so-called Pseudo-Boethii), and Gerbert of Aurillac (905-1003, Pope Sylvester II), who also adopted Arabic knowledge.

The economic, social and political development of the country has also been reflected in the surveying field. King of Bohemia, Margrave of Moravia, Duke of Austria, Ottokar II of Bohemia (1233-1278) initiated a reform of land measures. Under his rule, Czech land tables (České desky zemské) were established along with the position of a land surveyor (Hánek and Hánek, 2018). České desky zemské is the predecessor of a land registry for real estates. They served as a model for similar Moravian and Silesian registers. They began to lose their significance from the end of the 18th century. Based on Zemské desky, other official books (e.g. municipal) were es- 
tablished and kept as early as the 13th century, not only in the Czech lands, but also in Poland, Brandenburg and some Austrian lands. Charles IV founded a university as a Central European educational institution in 1348. King of Bohemia and Hungary Vladislaus II established a price list of surveying works (1500) as part of the new land order. The first map of Bohemia by Mikoláš Klaudyán dates from 1518. An unknown author drew the first map of Silesia in 1545 and in 1562 Paul Fabricius the first map of Moravia.

\section{History of instrument production in the time of Holy Roman Emperor Rudolf II}

In 1583, Holy Roman Emperor Rudolf II (1552-1612) relocated to Prague. After almost two centuries, it has once again become a major cosmopolitan European capital. At the invitation of Tadeáš Hájek from Hájek, a naturalist and the author of the first triangulation of Prague cities, Tycho Brahe and Johann Kepler came to Prague. A number of important European mechanics and designers worked at the court of the monarch. Many of their works were soon lost or transported to other countries during the Thirty Years' War.

A native of Switzerland, Jost Bürgi (1552-1632) worked at the court in Kassel. In 1604 he was appointed imperial watchmaker in Prague, but 2 years earlier his products had been protected by the monarch. In 1609, Bürgi designed a triangulation instrument for Landgrave William IV of HesseKassel. In 1610 he compiled and only in 1620 published logarithmic tables, which were also used by Johann Kepler. At the beginning of the 17th century, his collaborator Heinrich Stolle created a gilded theodolite with a diopter (Fig. 1), an azimuthal sundial and a set of mathematical functions. This unique device is now protected in the world-famous astrometric collections of the National Technical Museum (NTM) in Prague. Erasmus Habermel (1538?-1606) is the author of perfect mobile sundials with an altimeter. For Francesco Padua di Forli, the emperor's personal physician, he created a set of mathematical tools (e.g. archipendulum, drawing instrument, reduction compasses). In 2016, the highly valued astronomical sextants by Jost Bürgi and Erasmus Habermel from the NTM collections were declared a National Cultural Treasure of the Czech Republic by a decree of the Government of the Czech Republic. Of course, these masters also influenced other designers and manufacturers not only in Prague. The level of production was high. In the first half of the 16th century, Bishop Jan Skála of Doubravka (Jan Dubravius) designed and used a gravity levelling device with a diopter for the construction of Moravian ponds.

\section{Production during the industrial revolution}

The Thirty Years' War caused a drastic reduction in the Czech population, irreversible cultural losses, the emigration of Protestant elites, massive re-Catholicization and Ger-

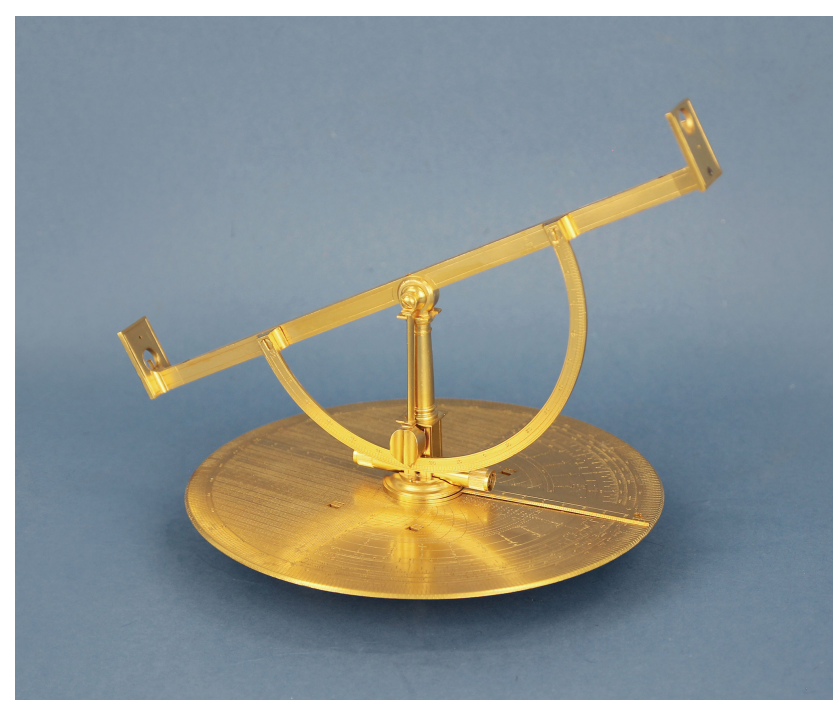

Figure 1. Theodolite by Stolle (photo supplied by https://www. surveyinginstruments.org, last access: 21 September 2021).

manization. There were fundamental changes of ownership mostly in favour of the foreign nobility. In connection with this, however, there was later an extensive construction of representative church and manor buildings. Specialties of fine mechanics were rarely produced, mainly for nobles, for example by Master Moser in Prague in the second half of the 18th century. Most precision instruments were imported. In smaller workshops, tools were produced for basic measuring and mapping, especially for hydrotechnical demarcation work in connection with the extensive establishment of ponds.

The revival did not occur until the 18th and 19th centuries. Kristian Josef Willenberg founded the Estates University in Prague in 1705, the predecessor of today's Czech Technical University in Prague (CTU). In the Czech Kingdom, the cultural and political so-called Czech national revival took place within the Austrian Empire. This corresponded to a growing economic value of the Czech lands as well as of a number of qualified Czech workforce and of a developing intelligence.

In the area of production of measuring instruments, the products signed by the name Spitra showed above-average quality. An example of a levelling device is in Fig. 2. Three generations of this family (František, Václav Michal, Otakar) worked in Prague from 1820 to the end of the 19th century.

From about 1840, the workshop of master Mathias Richard Brandeis (1818-1868) was active. After his death, the plant was taken over by the company of Hasse and Wilhelm. An example of a tachymeter from Hasse and Wilhelm is in Fig. 3. In 1890, 24 companies produced surveying instruments and tools only in Prague; at the end of the century it was already 40. Among the best known are the workshops Hauser, Jaklin, and Šebek and workshops from the end century Durst, Dušek. 


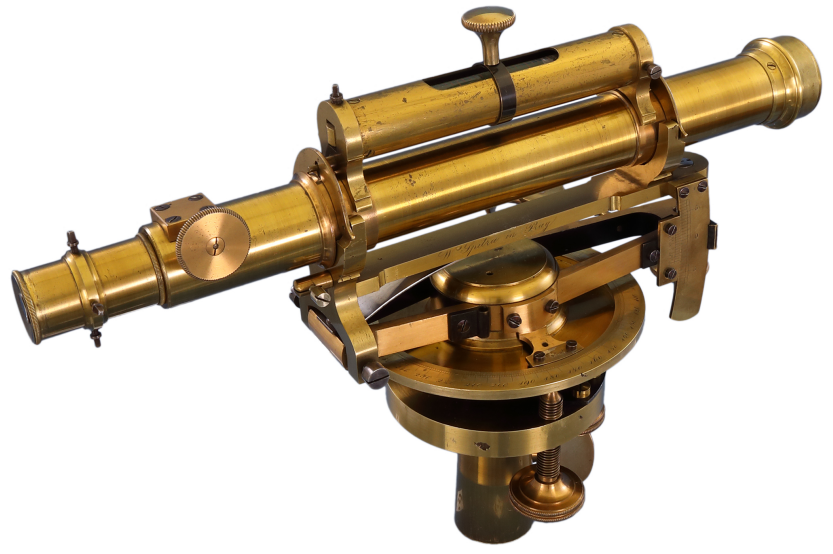

Figure 2. Levelling instrument by Spitra (photo supplied by https: //www.surveyinginstruments.org).

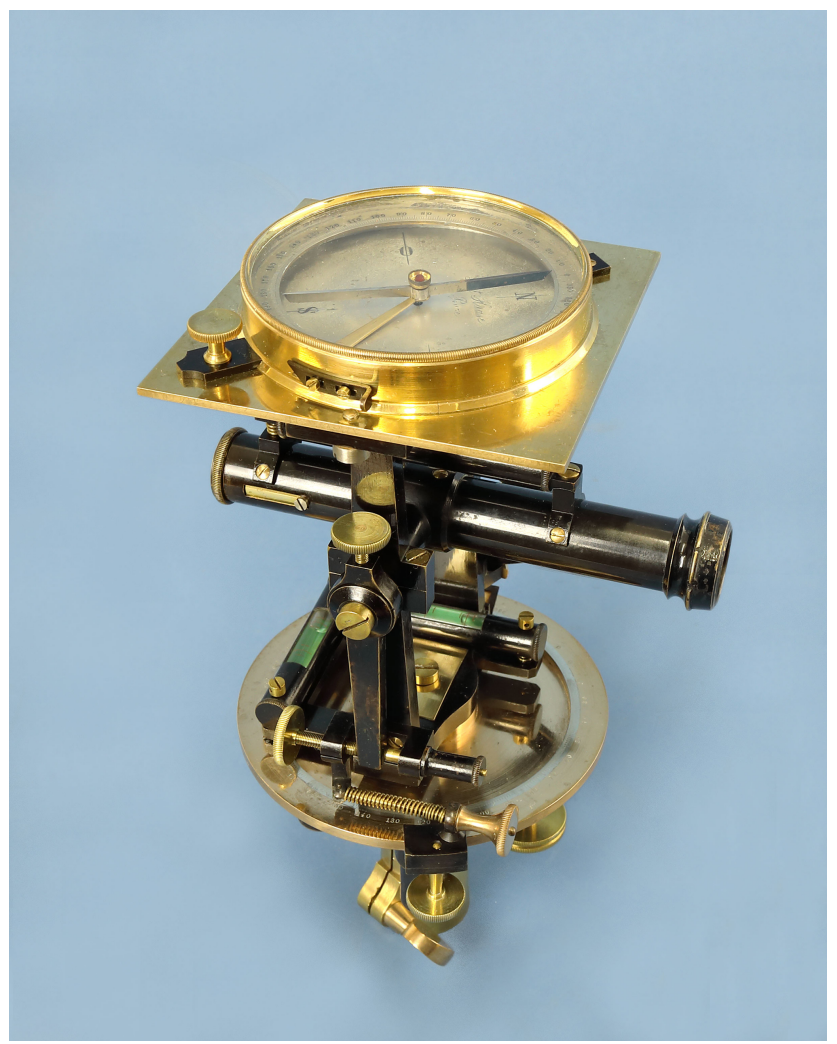

Figure 3. Tachymeter by Hasse and Wilhelm (photo supplied by https://www.surveyinginstruments.org).

Others were Poskočil in the town of Libochovice and Karl Gangloff in Rožmitál. These manufacturers offered almost the entire range, thus instruments for magnetic measuring, geodetic astrolabes, tools for setting angles of a constant size, clinometers, liquid and levelling bubble instruments and level staffs, theodolites and tacheometers, forestry dendrometers, plane tables, measuring chains, rods and tapes.
At the end of the 19th century, professors of the Czech Technical University ${ }^{1}$, František Müller and František Novotný, designed some instruments for accurate measuring and mapping.

Also known is the mirror hypsometer by Prof. Dr. Karel Eduard Kořistka for elevation mapping. Antonín Tichý designed a precision tacheometer with a logarithmic rangefinder manufactured by Starke \& Kammerer. Prof. Václav Láska made the construction of the autoreduction tacheometer, which was also manufactured in Vienna. Professor Franz Kreuter from Brno built a universal autoreduction tacheometer for the Reichenbach Institute in Munich.

\section{Production in the period 1883-1945}

In 1883, brothers Josef (1861-1945, after the death of his brother, he started to use the name Josef Jan) and Jan (18631897) Frič founded a company for precision mechanics in Prague. The talent and professional interest of both brothers were very broad and creative. We can mention, for example, the production of special equipment and machines used for production in their own company (Frič, 1931). They also made constructions for physical and chemical analyses. In 1906, the Frič bareoscope and polarimeter were introduced in the USA as an official standard in the sugar industry. The family company J. \& J. Frič also manufactured a wide range of geodetic and topographic instruments, including special instruments for deformation measuring in tunnels and dams. These also include the triangulation theodolite $6 \mathrm{R}$ with screw microscopes, enabling reading of 1 arcsec. Theodolite 6R was later used for measured in the Czechoslovak trigonometric network. In the years 1884-1885, a small series of $10-12$ pieces of mining theodolite DUPLEX ${ }^{2}$ was produced, in which a glass horizontal circle was used for the first time in the world (Fig. 4). The authors published this design in 1886 in the German magazine Zeitschrift für Instrumentenkunde (Frič and Frič, 1886), when the device was also presented at a conference of mining engineers in Budapest. This repetition theodolite was used for the astronomical and mine-geodetic measuring, for connection survey, orientation measurement and for measuring with a steep sight. Two telescopes were used for easy targeting. The right-angled axis of the eccentric telescope for steep measuring passed through the concave trunnion axis of the main centric telescope. The horizontal circle with a diameter of $130 \mathrm{~mm}$ was made of mirror glass with a thickness of $8 \mathrm{~mm}$. The engraved division with

\footnotetext{
${ }^{1}$ The 2-year surveying study was established by a decree of the relevant ministry in 1896 .

${ }^{2}$ Theodolite is exhibited in the Moravian Cartographic Center in Velké Opatovice (owner is VSB - Technical University of Ostrava - Faculty of Mining and Geology), or it is possible to look at the device at https://www.surveyinginstruments.org/col/instrument/ show?instrumentId=143, last access: 21 September 2021.
} 


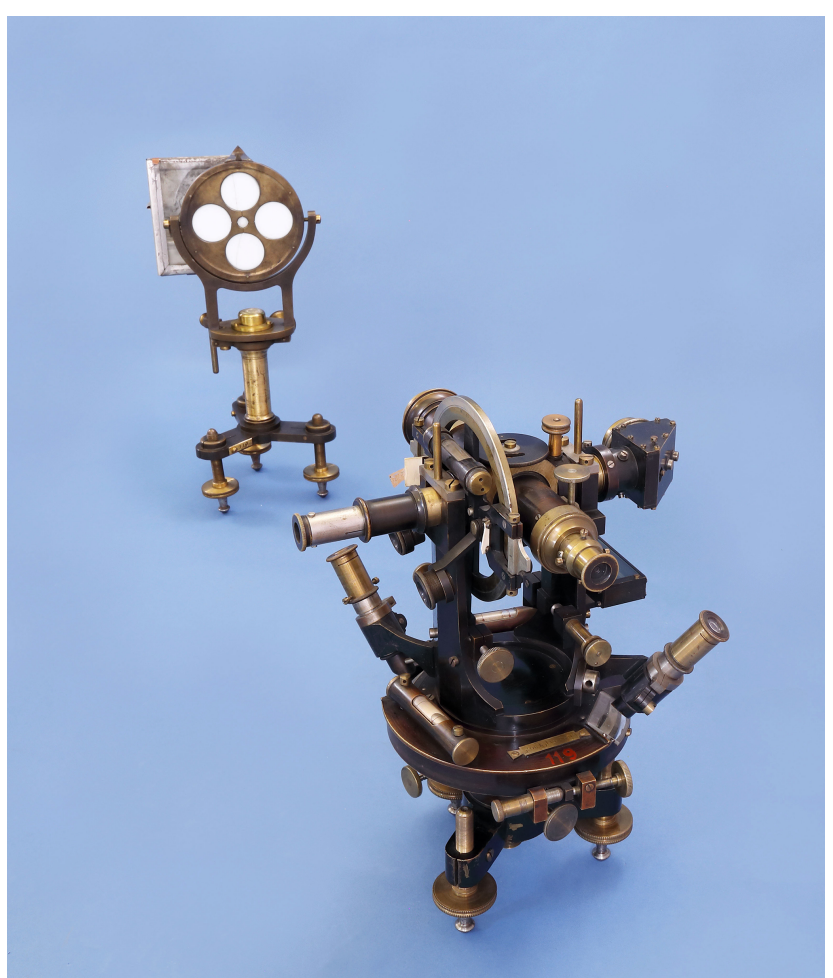

Figure 4. Theodolite DUPLEX by J. \& J. Frič company (photo supplied by https://www.surveyinginstruments.org).

an interval of $1^{\circ}$ was illuminated by two windows from below using a mining lamp. Accuracy of 30 arcsec was achieved using two microscopes with $24 \times$ magnification (Hánek and Švejda, 1993). At the international exhibition in Brussels in 1888, the J. \& J. Frič company presented another novelty, a hanging mining compass of the Kassel type (Fig. 5). The magnetic knife needle was damped by a friction mica disc, and a reading equipment with a vernier was placed on the tip of the needle. The reading accuracy of the clock circle was 360 arcsec. According to the proposal of Prof. František Nušl, a circumzenithal was designed and successfully manufactured by Josef Jan Frič. This astrolabe device was used to determine geographical coordinates by the method of equal heights, achieving a positioning accuracy of $1.5 \mathrm{~m}$. The J. \& J. Frič company produced a complete range of geodetic instruments and aids. Typical features of almost all older theodolites are control knobs made of dark red plastic.

\section{Czechoslovak production}

The J. \& J. Frič company began to focus more on the production of astronomical instruments from the 1920s, and its geodetic instruments became obsolete. After nationalization in 1950, the company became part of Metra company and was transferred to another production.

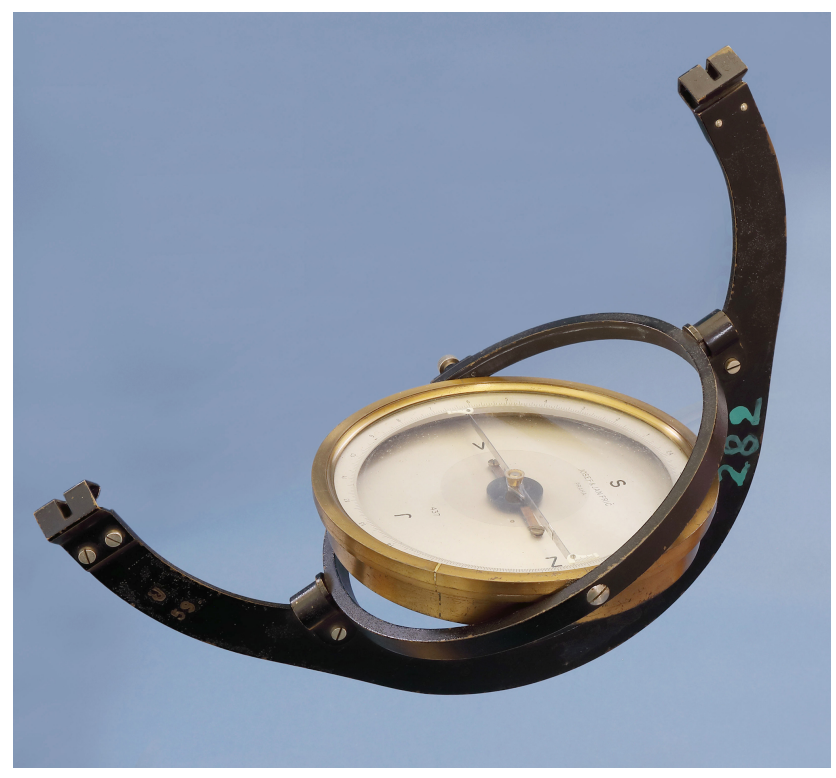

Figure 5. Hanging compass by J. \& J. Frič company (photo supplied by https://www.surveyinginstruments.org).

At the end of 1919, Jaroslav Srb (1892-1967) and Josef Štys (1895-1950) established a plant of fine mechanics and optics in the newly formed Czechoslovak Republic in Prague (Srb, 1950). Both partners went through an internship at Carl Zeiss in Jena. The company introduced modern forms of work organization, gained military contracts and experienced workers from the J. \& J. Frič company. In 1923, the company established its own optical lens grinding shop. In the 1930s, it had sales offices in Istanbul, London and Bucharest, where a Romanian-Czechoslovak optical company was established. The plant manufactured microscopes, epidiascopes, telescopes, binoculars, sights (military and hunting), periscopes, meteorological instruments and laboratory equipment, including forensic ones. The products were exported to a number of European countries, but also to the USA, China and India. In 1939, the company bought a company for the production of spectacle lenses and a carpentry shop and built its own glassworks. A significant part of the production of the company Srb \& Štys was a complete range of geodetic instruments and tools. In 1921, levelling device no. 1 with a bubble level sensitivity of 15 arcsec. and a horizontal circle was offered; device no. 2 was also mounted on a tripod head. In 1927, a triangulation theodolite was produced (magnification of the telescope $26 \times$, sensitivity of alidade cross levels of 18 arcsec, detachable bubble levels 5.0 arcsec, microscope reading by estimate 1 arcsec). Other devices were the repetition theodolite Th I with microscopes (estimate 6 arcsec), the universal theodolite Th II, the tacheometer Th III and the uniaxial school theodolite Th $\breve{S}$. In 1938 Srb \& Štys offered biaxial uniaxial theodolites Th N with a magnification of $25 \times$ or $20 \times$. The metal horizontal and vertical circles were produced with a 60 th or 100th an- 


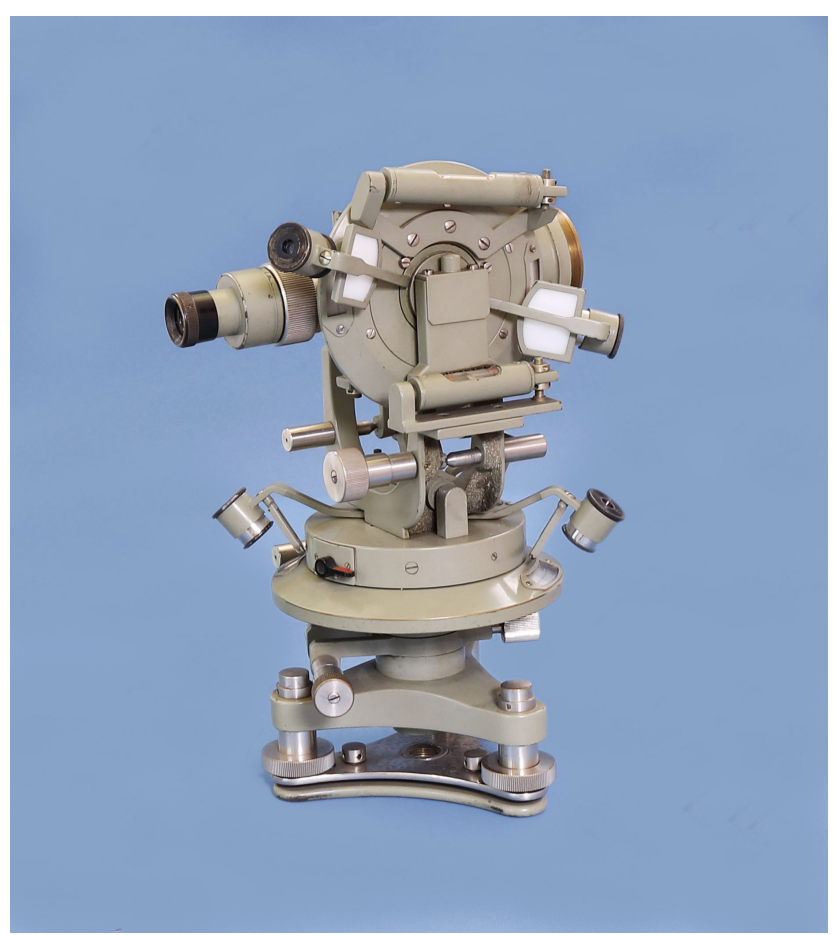

Figure 6. Compass theodolite by Srb \& Štys company (photo supplied by https://www.surveyinginstruments.org).

gular division, empirical mean error of the horizontal direction of 10.3 arcsec, vertical angle of 7.2 arcsec, sensitivity of alidade levels approximately 35 arcsec, levels on telescope 22.0 arcsec. The accessories for the theodolites included a two-image rangefinder (Aregger's wedge) with a pair of invar rods, battery lighting, and a detachable compass. The compass theodolite Th B (Fig. 6), based on Th $\mathrm{N}$ models, was offered. There were also some special constructions, for example a balloon theodolite ${ }^{3}$ with night lighting. Furthermore, a device for aiming inaccessible targets, such as changes in the water level, worked on the principle of the forward intersection method. The fixed telescope of the NN levelling bubble instrument was taken over from the theodolite Th $\mathrm{N}$ $25 \times$. The levelling device NNK was further equipped with a horizontal circle read by index. The so-called K. N. H. pocket levelling device, comparable in weight to a camera, was supposed to allow a measuring distance of up to $60 \mathrm{~m}$ in common construction practice. Further the offer included a plane table supplied with either an alidade with a telescopic sight and a vertical circle corresponding to Th $\mathrm{N} 25 \times$, or only with view ports. The company also produced tripods, angle mirrors, prisms, heads, geological compasses, mining hanging compasses, clinometers and rods (Hánek and Švejda, 2019).

In 1933, Alois Mazurek founded the company Optikotechna in Přerov. In 1935, his partner sold the successful company to the arms company Zbrojovka Brno. The

\footnotetext{
${ }^{3}$ Theodolite was used for measured to meteorological balloons.
}

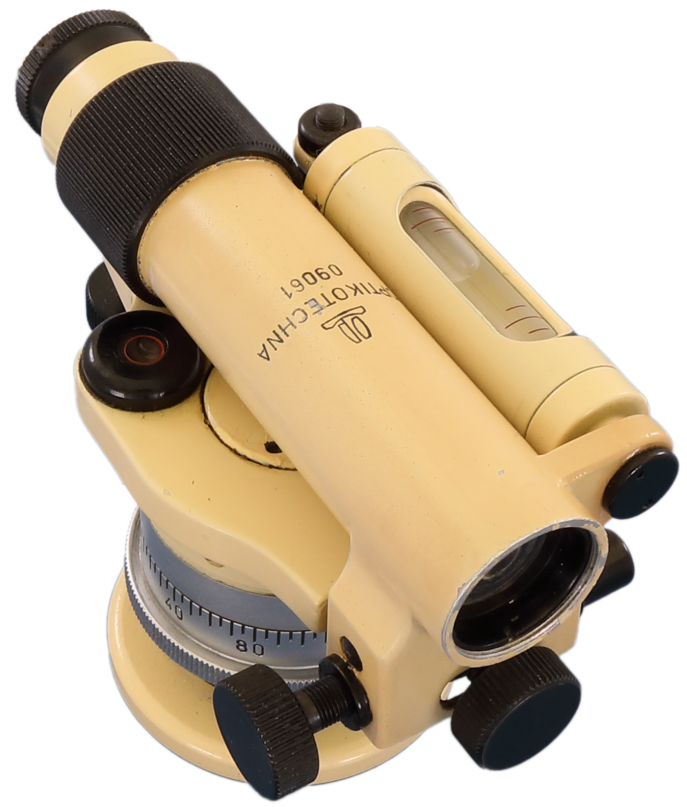

Figure 7. Levelling instrument by Optikotechna company (photo supplied by https://www.surveyinginstruments.org).

company specialized in the production of photographic and projection devices. It also produced levelling instruments in small numbers (an example is shown in Fig. 7) and for the Czechoslovak army small photogrammetric instruments and stereocomparators. From 1937, they started exporting to the USA.

In the first half of the 20th century, the Prague-based company Koula produced aerial handheld photogrammetric cameras and large-format cameras for map reproduction. The designer Mahr built a unique prototype of a photogrammetric rectifier of aerial photographs with a tilted axis. Haager built aerial photogrammetric cameras for the Czechoslovak army. The Prague-based companies Strejc and Dušek were known for their drawing instruments (Hánek, 2001, 2003).

During the so-called Protectorate of Bohemia and Moravia, i.e. during World War II, all these companies were subject to German war production.

\section{Czechoslovak production in the second half of the 20th century}

In 1945, the companies Optikotechna, the optical department of Srb \& Štys, and some others were nationalized and merged by the Decrees of the President of the Republic (known as the Beneš decrees). The new national enterprise Meopta in Prague initially continued to manufacture geodetic instruments of the Srb \& Štys company. From 1946, a successful theodolite Th $30 \times$ with metal circles read by a pair of verniers (the mean error of the horizontal direction was 15 to $18 \mathrm{arcsec}$, the vertical angle 10 to $15 \mathrm{arcsec}$ ) was pro- 
duced. Typical features were the coaxial clamps according to A. Holýs patent. After 1955, the T1c theodolite with glass circles designed by A. Dvořák was manufactured. It was equipped with a built-in tubular compass, horizontal circle drive knob and reading by simple optical micrometer enabling estimation up to 2 mgon. For an army, the Th 60 was made with a detachable periscope and milliradian circle division. Their offer also included a balloon (meteorological) theodolite and a topographic set. The spirit level N $25 \times$ $(\sigma=4.0 \mathrm{~mm} / \mathrm{km})$ was replaced by $\mathrm{N} 30 \times(\sigma=2.5 \mathrm{~mm} / \mathrm{km})$. The NK $30 \times$ had a glass horizontal circle read by the scale microscope (grid) to 300 arcsec. The image of the coincident ends of the bubble level was in the field of view of the telescope. The MN 10 type was developed for construction use. The last model produced was the MNK 20 (Fig. 8) for levelling $(\sigma=4.0 \mathrm{~mm} / \mathrm{km})$ with the compensator of the Urban and Prribyl designers with a sensitivity of 0.8 arcsec and a settlement time of $1.5 \mathrm{~s}$. and with an endless fine clamp. The microscope scale for the horizontal circle reading had the smallest division of $300 \mathrm{arcsec}$. In addition to theodolites and levelling instruments, other devices were also manufactured, such as an eclimeter (Fig. 9). In 1961, a new series of theodolites MT 0 theodolites (the telescope magnification $15 \times$, the accuracy of reading the horizontal and vertical circle 5 mgon) was prepared, with glass circles the MT 10 (the telescope magnification $28 \times$, the accuracy of reading the horizontal and vertical circle $10 \mathrm{mgon}$ or 30 arcsec, optical optical centring feature, level vial on the telescope upon request), MT 11 with an automatic vertical circle index, MT 20 with horizontal circle drive knob and reading up to $10 \mathrm{cc}$ by optical micrometer and a second MT 30 (the telescope magnification $34 \times)$. None of these devices were mass produced and used in practice, nor did the school and compass type of theodolite or the precision levelling device MN 20 with a micrometer. In 1963 the production was suddenly abolished and delimited within the then Council for Mutual Economic Assistance of the so-called socialist countries. Meopta Praha was incorporated into the Industrial Automation Plant (ZPA) with a new programme. In the 1980s it was offering construction lasers. After privatization, Meopta Přerov now has a foreign owner and a sister plant in New York. It has been known for producing sports and hunting riflescopes (gun sights) and binoculars.

The Research Institute of Geodesy, Topography and Cartography v.v.i. Zdiby (VÚGTK) was founded in 1954 in Prague. In small series or only as a prototype, it has produced special devices and tools, such as the circumzenithal 100/1000 (Fig. 10) and its field version 50/500, invar tapes, drafting cartographic sets. In the 1950s, it designed a functional prototype of an electro-optical rangefinder.

Tesla was founded in 1946 as a state-owned enterprise; in 1990 it became a joint-stock company. With its production, based in dozens of plants, it covered the entire field of electrical engineering for consumer, civil and military needs. A

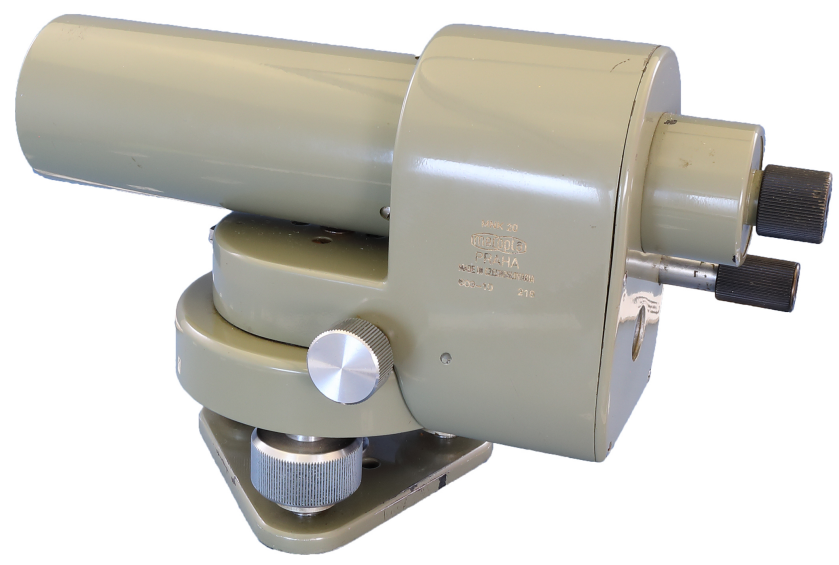

Figure 8. Levelling instrument MNK20 by Meopta company (photo supplied by https://www.surveyinginstruments.org).

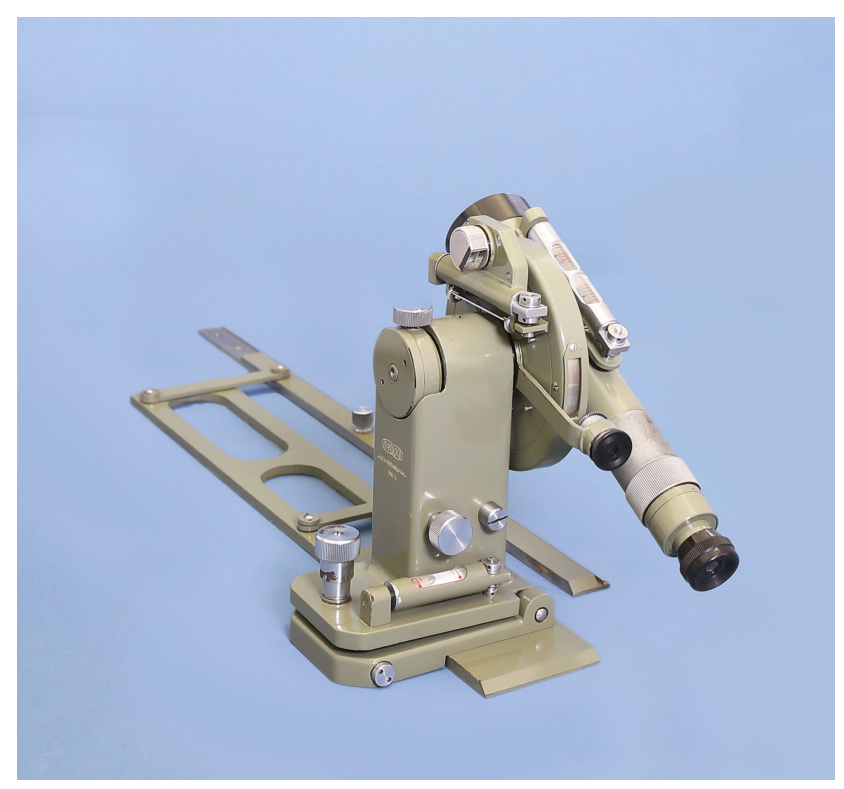

Figure 9. Eclimeter by Meopta company (photo supplied by https: //www.surveyinginstruments.org).

high-quality He-Ne layout laser TKG 20 (Fig. 11) was manufactured.

Various tools and small instruments were manufactured by other companies, such as tape measures by Kinex, cartographic tools and planimeters by Metra, and slide rulers and templates by Logarex. Today, for the surveying field the plants of optics and fine mechanics in the Czech Republic produce only small tools or parts and accessories for foreign companies.

\section{Conclusion}

The Ministry of Culture of the Czech Republic has been running the National Cultural Identity (NAKI) programme 


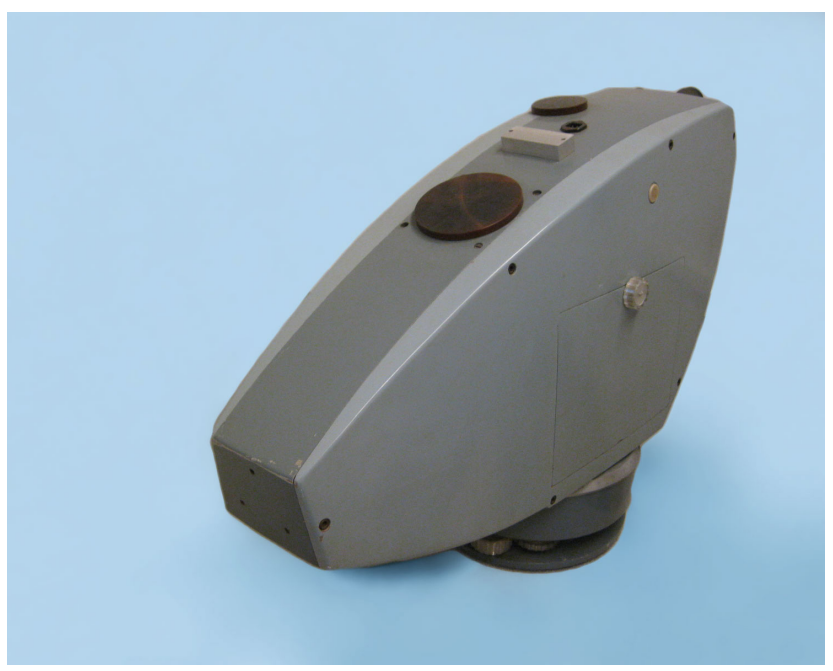

Figure 10. Circumzenithal by Research Institute of Geodesy, Topography and Cartography (photo by Pavel Hánek).

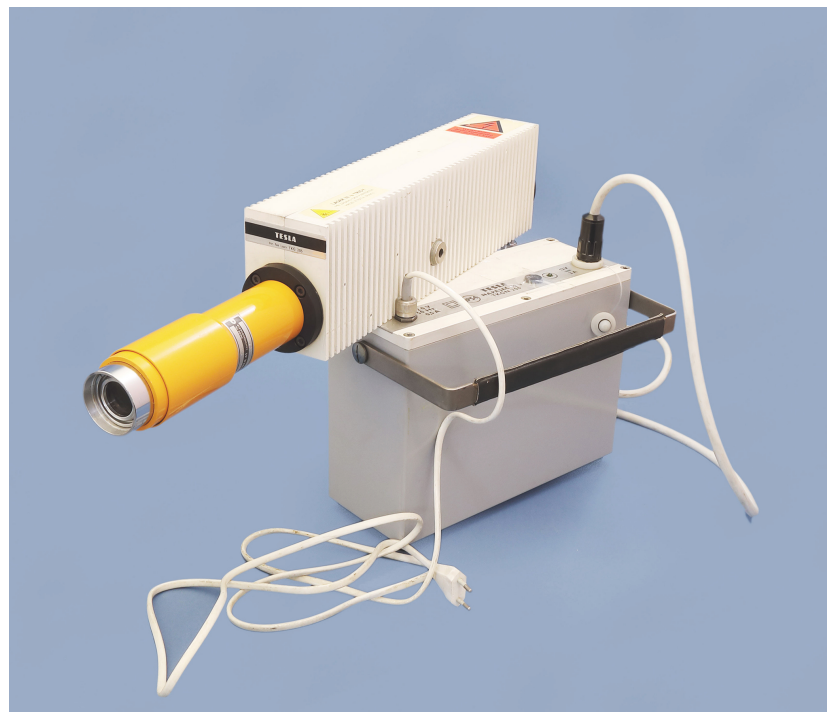

Figure 11. Layout Laser TKG 205 by Tesla company (photo supplied by https://www.surveyinginstruments.org).

for several years. Within its framework, grant projects are awarded, aimed at significant manifestation of the nation's tangible cultural and technical heritage. There is a rich history of surveying and cartography in the Czech Republic and the tradition of production of surveying and astronomicalgeodetic instruments and tools. That is why VÚGTK, together with National Technical Museum (NTM), won a project focused on devices used in the Czech Republic from the 16th to the end of the 20th century. The documented devices come from the collections of museums, schools, institutions and private ones. To date, more than 200 instruments from 32 European manufacturers have been documented.
Data availability. Selected visual and textual information about the instruments will be available at https: //www.surveyinginstruments.org (last access: 21 September 2021; Hánek et al., 2020). The web portal is currently only available in the development version, which has been created in Czech language. After the completion of the project, it will also be available in English.

The document ( $\mathrm{Srb}, 1950)$ is available in the archive of the National Technical Museum.

Author contributions. Authors conceived and designed the whole article together. All authors read and approved the paper. $\mathrm{PH}$ prepared and selected the pictures.

Competing interests. The contact author has declared that neither they nor their co-author has any competing interests.

Disclaimer. Publisher's note: Copernicus Publications remains neutral with regard to jurisdictional claims in published maps and institutional affiliations.

Acknowledgements. The authors wish to thank the editor, the three reviewers and Viola Zierenberg, for their assistance and valuable suggestions. The authors also thank the Ministry of Culture of the Czech Republic for financial support of the research project DG18P02OVV054 - Surveying and astronomical instruments used in the Czech Republic from the 16th to the end of the 20th century.

Financial support. This research has been supported by the Ministerstvo Kultury (grant no. DG18P02OVV054).

Review statement. This paper was edited by Johannes Ihde and reviewed by Wolfgang Dick, Andreas Reinhold, and one anonymous referee.

\section{References}

Frič, J. and Frič, J.: Der neue Grubentheodolit "Duplex”, Z. Instrumentenkd., 6, part 2, 305-308, 1886.

Frič, J. J.: O vzniku a rozvoji vlastního závodu, J. \& J. Frič company, Prague, 1931.

Hánek Sr., P.: Tradition geodätischer Instrumente in Tschechien. Vermessung, Photogrammetrie, Kulturtechnik/Mensuration, Photogrammétrie, Génie Rural, 99, 237-241, 2001.

Hánek Sr., P.: Instruments used in Czech technical surveying in 19th and 20th centuries, Proceedings of the 11th International Scientific Conference Science, Education and Society, Section No. 1 - Enginering Constructions, Žilina, University of Žilina, 39-42, 2003. 
Hánek Sr., P. and Hánek, P.: 750 let od úpravy zemských měr, Geodetický a kartografický obzor (GaKO, česky), 64, 222-225, 2018 (in Czech).

Hánek Sr., P. and Švejda, A.: Důlní teodolit DUPLEX firmy J. a J. Frič. II. konference Měřické přístroje a výpočetní technika historie a současnost, Ostrava, SDMG, 35-39, 1993 (in Czech).

Hánek Sr., P. and Švejda, A.: K 100. výročí založení firmy Srb a Štys, GaKO, 65, 162-167, 2019 (in Czech).
Hánek, P., Hánek Sr., P., and Vacková, K.: Documentation of old surveying instruments, in: Trends in Geodesy, edited by: Melčíková, S., Hurčíková, V., and Blištan, P., Cartography and Geeoinformatics II. London, Taylor \& Francis Group 2020, 24 29, https://doi.org/10.1201/9780429327025, 2020.

Srb, J.: Vývoj firmy Srb a Štys - počátky výroby optických př́strojů v ČSR, Prague, 1950 (in Czech). 